\title{
Biosorption of Chromium by Agricultural Waste, Anacardium Occidentale Testa Powder: Characterization, Kinetic, Isotherm and Thermodynamic Studies
}

SWARNALATHA GUNDLAPALLI ( $\nabla$ swarnampharm@gmail.com )

Mahathi College of Pharmacy https://orcid.org/0000-0002-5681-3620

Chandrakala Gunturu

Center for Biotechnology, Department of Chemical Engineering Andhra University, Visakhapatnam-530 003, India

\section{Sureddy V Naidu}

Center for Biotechnology, Department of Chemical Engineering Andhra University, Visakhapatnam-530 003, India

\section{Research}

Keywords: Biosorption, Anacardium occidentale testa powder, Chromium, Kinetics, SEM

Posted Date: November 2nd, 2021

DOI: https://doi.org/10.21203/rs.3.rs-922055/v1

License: (c) (i) This work is licensed under a Creative Commons Attribution 4.0 International License.

Read Full License 


\title{
Biosorption of chromium by agricultural waste, Anacardium occidentale testa powder: characterization, kinetic, isothermic and thermodynamic studies
}

\author{
Swarnalatha. $\mathrm{G}^{1 *}$, Chandrakala Gunturu ${ }^{1}$ and Sureddy V Naidu ${ }^{2}$
}

Correspondence: swarnapchem@gmail.com

$1 *$ Current address: ${ }^{*}$ Department of Chemistry, Mahathi College of Pharmacy, Madanapalli-Andhra Pradesh- 517319, India.

\begin{abstract}
The study on low-cost biosorbent such as Anacardium occidentale testa powder was used to remove chromium from aqueous solutions. Based on $R^{2}$ values, the Langmuir $\left(R^{2}=0.9927\right)$ model fitted the equilibrium biosorption data best, confirming monolayer adsorption of chromium on to the biosorbent surface. The biosorption of chromium was best described by pseudo-second order $\left(\mathrm{R}^{2}\right.$ $=0.9902$ ) kinetics since at all concentrations, the $\mathrm{R}^{2}$ values were higher than the corresponding pseudofirst order $\left(\mathrm{R}^{2}=0.9278\right)$ values. Based on thermodynamic parameters the biosorption of chromium by Anacardium occidentale testa powder was found to be spontaneous, endothermic and feasible under optimized conditions.
\end{abstract}

Keywords: Biosorption, Anacardium occidentale testa powder, Chromium, Kinetics, SEM

\section{Introduction}

Industries like fuel production units, atomic energy stations, electroplating and fertilizer industry, leather and electrical appliance manufactory, and iron enterprises generate enormous wastes containing large amount of toxic heavy metals discarded into the environment resulting in ecological imbalance (Kümmerer 2009). Numerous disorders and diseases are caused by the deposition of heavy metals like lead, mercury, cadmium and chromium at the top of the toxicity list (Fu and Wang 2011)

Chromium exists in several oxidation states, but the most stable and common forms are $\mathrm{Cr}(0)$, the trivalent $\mathrm{Cr}$ (III), and the hexavalent $\mathrm{Cr}(\mathrm{VI})$ species. $\mathrm{Cr}$ (VI) in the forms of chromate $\left(\mathrm{CrO}_{4}{ }^{2-}\right)$, dichromate $\left(\mathrm{Cr}_{2} \mathrm{O}_{7}{ }^{2-}\right)$, and $\mathrm{CrO}_{3}$ are considered the most toxic forms of chromium, as it presents high oxidizing potential, high solubility, and mobility across the membranes in living organisms and in the environment. The main source of $\mathrm{Cr}$ (VI) ions are produced from industries like plating, alloying, tanning, water corrosion, textile, pigments, ceramic glazes, refractory bricks, and pressure- 
treated lumber industries (Avudainayagam et al.2003). Cr-VI ions are more toxic than $\mathrm{Cr}$-III ions, $\mathrm{Cr}$ (VI) ions are powerful epithelial irritant and also considered as a human carcinogen. $\mathrm{Cr}$ (VI) ions are toxic to many plants (Shanker et al. 2005) aquatic animals (Velma et al. 2009), and microorganisms (Petrilli Flora De 1977). It also been reported that human kidney and liver are damaged due to high chromium dosage (Mungasavalli et al. 2007) and in low doses it causes skin irritation and ulceration (Karthikeyan et al. 2005) Many studies identified that $10 \mathrm{ppm} \mathrm{Cr}$ (VI) ions as the threshold at which not more than $10 \%$ of exposed individuals developed skin sensitization. Chronic health effects are observed in human population when exposed to approximately $20,000 \mu \mathrm{g} \mathrm{Cr}-\mathrm{VI} / \mathrm{L}$ in drinking water contaminated by a ferrochrome plant caused mouth sores, diarrhea, stomach pain, indigestion, vomiting, and higher levels of white blood cells than the reference population. Environmental Protection Agency has concluded that the only chromium (VI) should be classified as a human carcinogen. Exposure to chromium (VI) ions resulted in complications during pregnancy and child birth. In aquatic ecosystems chromium causes hardness, rise in temperature, $\mathrm{pH}$, and salinity of water; and biological factors such as species, life stage, and potential differences in sensitivities of local populations (Marchese et al. 2008; Dwivedi et al. 2010). In animals $\mathrm{Cr}^{+6}$ produced cancers, reproductive harm, behavioral changes, reduced growth and survival using experimental doses through food, water or injections. Metallic $\mathrm{Cr}$ and $\mathrm{Cr}^{+3}$ are non-toxic (Gale 1978). When plants are exposed to excess chromium, toxic effects are reduced growth, decreased chlorophyll production causing yellow leaves, narrow leaves, small root systems, decreased or complete inhibition of seed germination, delayed growth, decreased seed yield, wilting and death (Dube et al. 2003; Zayed and Terry 2003). EPA has a drinking water standard of 0.1 milligrams per liter $(\mathrm{mg} / \mathrm{l})$ or 100 parts per billion $(\mathrm{ppb})$ for total chromium.

Among many conventional techniques (Nguyen et al. 2013), adsorption is very attractive owing to its easy operation and high efficiency to treat water contaminated with low concentrations of heavy metals, i.e., $<100 \mathrm{mg} / \mathrm{L}$. Continuous attempts were developed to produce low-cost adsorbents derived from industrial, agricultural and aquatic wastes e.g., cucumber peel (Basu et al. 2017), rapeseed biomass (Morosanu et al. 2017), cotton stalk and peanut hull (Ding et al. 2014), olive tree pruning waste (Calero et al. 2013), pine tree cone (Ofomaja and Naido 2010), Sea shell (Masukum et al. 2014), forest byproducts and waste (Cutillas-Barreiro et al. 2016; Waseem et al. 2014; Zhang et al. 2018), algae (Ibrahim et al. 2016), fungi (Dhankhar and Hooda 2011), agricultural waste (Mahmood-ul- Hassan et al.2015) Activated carbon (Mohan Singh 2002). Agricultural biomass wastes are promising raw materials since they are increasingly generated.

Anacardium occidentale testa powder can be used as a potential source of biosorbent. It belongs to the family Anacardiaceae, native to Northeast Brazil, India, Southeast Asia and Africa. The Cashew nut is a high value product from this tree but the testa is one of the by-product obtained from processing of cashew nuts, and it is not been considered as animal feed. The cashew nut testa is a reddish-brown skin that covers the cashew kernel. This skin is reported to be rich in hydrolysable 
tannins and polyphenols (Donkoh et al. 2012). Polyphenols, extracted from plants, are characterized by the abundant phenolic hydroxyls that are capable of chelating with transitionmetal ions, especially for those metal species with $d$-orbits (Zhang et al.2017). Because of the strong chelating ability of phenolic hydroxyls towards transition metals, the polyphenol-based cashew nut testa powder showed to be potential and efficient sorbent for the removal of chromium from aqueous solutions.

\section{Materials and methods}

\section{Preparation of Anacardium occidentale testa powder}

Anacardium occidentale testa was collected from Vetapalem, Prakasam, Andhra Pradesh. The testa were cleanly washed with water and then with distilled water, dried in sun until it became colorless and crispy. They were grinded to powder, separated into desired sizes using BSS sieves and stored in air tight plastic bags.

\section{Scanning electron Microscope (SEM) studies}

The pretreated biosorbent samples were examined in Scanning Electron Microscope and electron probe micro analyzer. The samples were coated with ultra-thin film of gold by an ion sputter JFC1100 and exposed under SEM.The working height was $15 \mathrm{~mm}$ with a voltage ranging from 10 to 15 $\mathrm{kV}$.The compositional image analyses of untreated and treated samples as shown in the Figures $1 \& 2$ were taken using equipment at $15 \mathrm{kV}$ and 40-100 nA beam current.

\section{Biosorption studies}

The initial concentrations of chromium in the aqueous solutions were analyzed in an Atomic absorption spectrophotometer (Perkin Elmer A Analyst 200 model) and found to be $20 \mathrm{mg} / \mathrm{L}$, wave length is $357.87 \mathrm{~nm}$, and sensitivity check is $4.0 \mathrm{mg} / \mathrm{L}$. The procedures adopted for the bio sorption of chromium is optimized by using following parameters.

\section{Effect of agitation time}

$50 \mathrm{~mL}$ of aqueous solution (initial concentration of chromium was $20 \mathrm{gm} / \mathrm{L}$ ) was taken in each 250 $\mathrm{mL}$ conical flasks and $10 \mathrm{~g} / \mathrm{L}$ of $53 \mu \mathrm{m}$ size biosorbent was added and exposed to varying agitation times $(3,5,10,15,20,25,30,40,50,60,90,120,150$ and $180 \mathrm{~min})$. These samples were shaken on an orbital shaker at $180 \mathrm{rpm}$ at $30^{\circ} \mathrm{C}$ for $1 \mathrm{~min}$. These samples were filtered separately with Whatman filter paper and the filtrates were analyzed in AAS to obtain final concentrations of chromium and the equilibrium agitation time was calculated and the data is shown in Figure 3. 


\section{Effect of biosorbent size}

$10 \mathrm{~g} / \mathrm{L}$ of biosorbent of different sizes $(53,75,105,125$ and $152 \mu \mathrm{m})$ were added to $250 \mathrm{~mL}$ conical flasks containing each $50 \mathrm{~mL}$ of aqueous solution and the contents were agitated in an orbital shaker. The optimum biosorbent size was determined from the data as shown in Figure 4.

\section{Effect of pH on the aqueous solution}

To study the influence of $\mathrm{pH}$ on chromium biosorption, $50 \mathrm{~mL}$ of aqueous solution was taken in 250 $\mathrm{mL}$ conical flasks. The $\mathrm{pH}$ values of the solutions were adjusted to $2,3,4,5,6,7$ and 8 in separate flasks by adding required amounts of $0.1 \mathrm{~N} \mathrm{H}_{2} \mathrm{SO}_{4}$ or $0.1 \mathrm{~N} \mathrm{NaOH} .10 \mathrm{~g} / \mathrm{L}$ of $53 \mu \mathrm{m}$ size biosorbent was added separately to these flasks. The samples were shaken on an orbital shaker at $30^{\circ} \mathrm{C}$ for equilibrium agitation time and the results are depicted as shown in the Figure 5.

\section{Effect of initial concentration on the chromium in aqueous solution}

$50 \mathrm{~mL}$ of aqueous solution was taken in a $250 \mathrm{~mL}$ conical flask using different concentrations $(20,50$, 80,120 and $150 \mathrm{mg} / \mathrm{L}$ ) and $10 \mathrm{~g} / \mathrm{L}$ of $53 \mu \mathrm{m}$ size biosorbent was added. The sample was kept in continuous contact for equilibrium agitation time by shaking on an orbital shaker at $30^{\circ} \mathrm{C}$ and the results were depicted as shown in the Figure 6.

\section{Effect biosorbent dosage}

The experiments were repeated for the dosages ranging from $(0.25,0.75,1.0,1.25,1.5,1.75,2.0,2.5$ and $3.0 \mathrm{~g}$ ) of $53 \mu \mathrm{m}$ size biosorbent for equilibrium agitation time. From these data, optimum biosorbent dosage was identified and the results were depicted as shown in the Figure7.

\section{Effect of temperature}

$50 \mathrm{~mL}$ of aqueous solution containing $20 \mathrm{mg} / \mathrm{L}$ of chromium was taken in $250 \mathrm{ml}$ of conical flasks. 10 $\mathrm{g} / \mathrm{L}$ of $53 \mu \mathrm{m}$ size adsorbent was added in each of these flasks and were shaken in an orbital shaker for equilibrium agitation time for five different temperatures $(283,293,303,313$ and $323 \mathrm{~K})$ and the results were depicted as shown in the Figure 8.

\section{Kinetic and thermodynamics studies}

In order to determine the order of the biosorption rate, $50 \mathrm{~mL}$ of aqueous solution containing $20 \mathrm{mg} / \mathrm{L}$ of chromium was taken in each of twelve conical flasks. $10 \mathrm{~g} / \mathrm{L}$ of $53 \mu \mathrm{m}$ size biosorbent was added in each flask. The conical flasks were shaken on an orbital shaker for different time intervals at $30^{\circ} \mathrm{C}$.They were settled, filtered and the filtrates were analyzed to find the final concentrations of chromium. The effect of temperature (283-323K) on biosorption rate and evaluation of the enthalpy of adsorption $(\Delta \mathrm{H})$, entropy of adsorption $(\Delta \mathrm{S})$ and Gibbs free energy $(\Delta \mathrm{G})$ were determined.

\section{Results and discussion}

The potential of dry Anacardium occidentale testa powder as a biosorbent for the biosorption of chromium metal present in an aqueous solution is determined. The effects of various parameters on biosorption of chromium are studied. The measured data consists of initial and final concentration of 
chromium in the aqueous solution, agitation time, biosorbent dosage, biosorbent size, $\mathrm{pH}$ of the aqueous solution and temperature of the aqueous solution. The experimental data are obtained by conducting batch experiments.

\section{SEM analysis for untreated and chromium treated Anacardium occidentale testa powder}

The analysis of untreated Anacardium occidentale testa powder as shown in Figure1 indicates that the powder is devoid of chromium. The Figure 2 shows the analysis of Anacardium occidentale testa powder loaded with chromium. The SEM analysis shows variation in the surface structure compared to unloaded one. Irregular spikes are accumulated on the surface and porous structure is also noticed indicating biosorption of chromium by Anacardium occidentale testa powder.

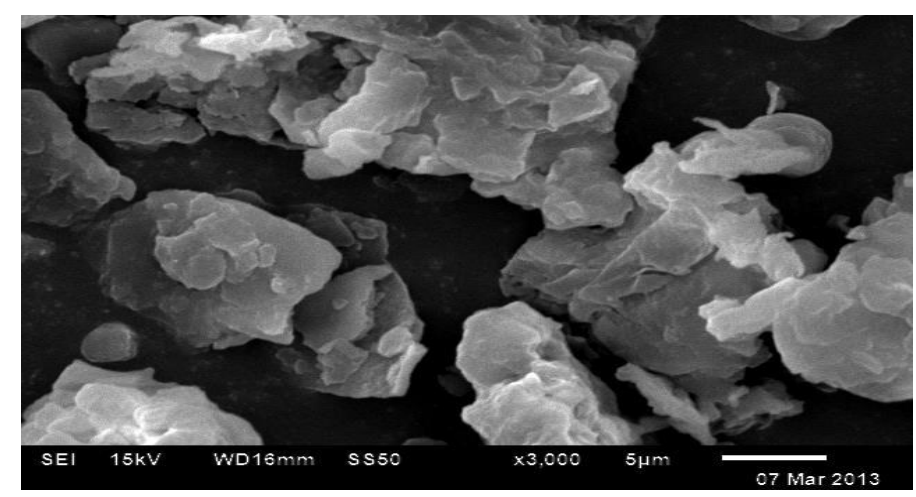

Fig.1 Electron micrographs of untreated Anacardium occidentale testa powder

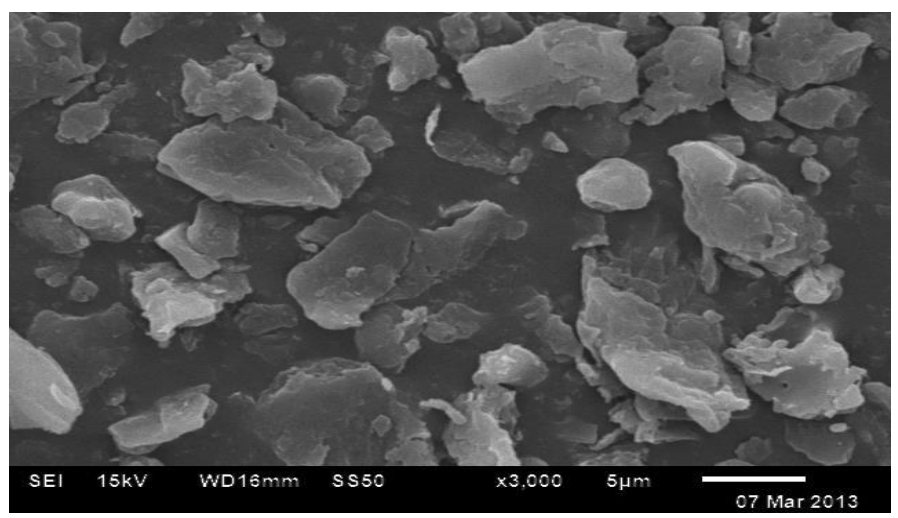

Fig.2 Electron micrographs of chromium treated Anacardium occidentale testa powder

\section{Effect of agitation time}

Duration of equilibrium biosorption is defined as the time required for heavy metal concentration to reach a constant value during biosorption. The equilibrium agitation time is determined by plotting the $\%$ biosorption of chromium against agitation time as shown in Figure 3, for the interaction time intervals between 1 to $180 \mathrm{~min}$. For $53 \mu \mathrm{m}$ size of $10 \mathrm{~g} / \mathrm{L}$ biosorbent dosage, $41.46 \%(2.058 \mathrm{mg} / \mathrm{g}) \mathrm{of}$ chromium is biosorbed in the first $5 \mathrm{~min}$. The \% biosorption is increased briskly up to $40 \mathrm{~min}$ reaching $59.16 \%(2.958 \mathrm{mg} / \mathrm{g})$. Beyond $50 \mathrm{~min}$, the \% biosorption is constant indicating the attainment of equilibrium conditions (Yun Wang et al. 2014; Rao Popuri et al. 2007) 


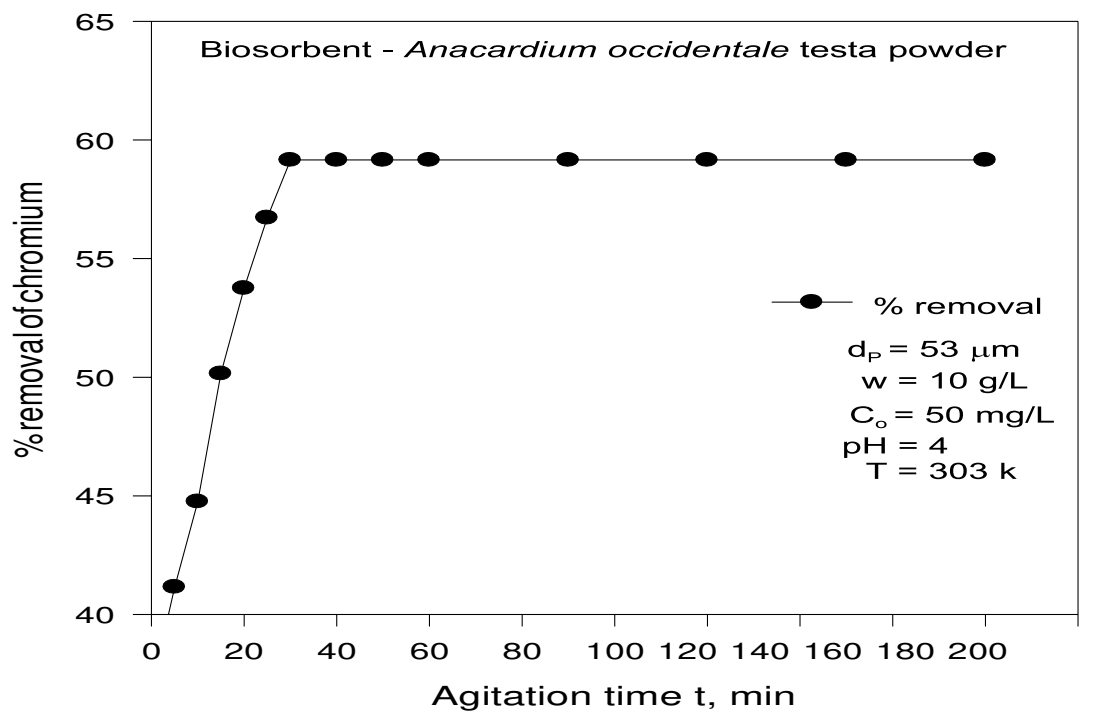

Fig.3 Effect of agitation time on \% biosorption of chromium

The rate of biosorption is fast in the initial stages because adequate surface area of the biosorbent is available for the biosorption of chromium. As time increases, more amount of chromium gets biosorbed onto the surface of the biosorbent due to Vanderwaal's forces of attraction and resulted in decrease of available surface area. The biosorbate, normally, forms a thin one molecule thick layer over the surface. When this monomolecular layer covers the surface, the biosorbent capacity is exhausted. The maximum percentage of biosorption is attained at 40 minutes. The percentage biosorption of chromium becomes constant after $40 \mathrm{~min}$. Therefore, all other experiments are conducted at this agitation time.

\section{Effect of biosorbent size}

The variations in \% biosorption of chromium from the aqueous solution with biosorbent size are obtained. The results are drawn in Figure 4 with percentage biosorption of chromium as a function of biosorbent size. The percentage biosorption is increased from $42.72(2.136 \mathrm{mg} / \mathrm{g})$ to $59.08(2.954$ $\mathrm{mg} / \mathrm{g}$ ) as the biosorbent size decreases from 150 to $53 \mu \mathrm{m}$. This phenomenon is expected, as the size of the particle decreases, surface area of the biosorbent increases; thereby the numbers of active sites on the biosorbent are better exposed to the biosorbate. 


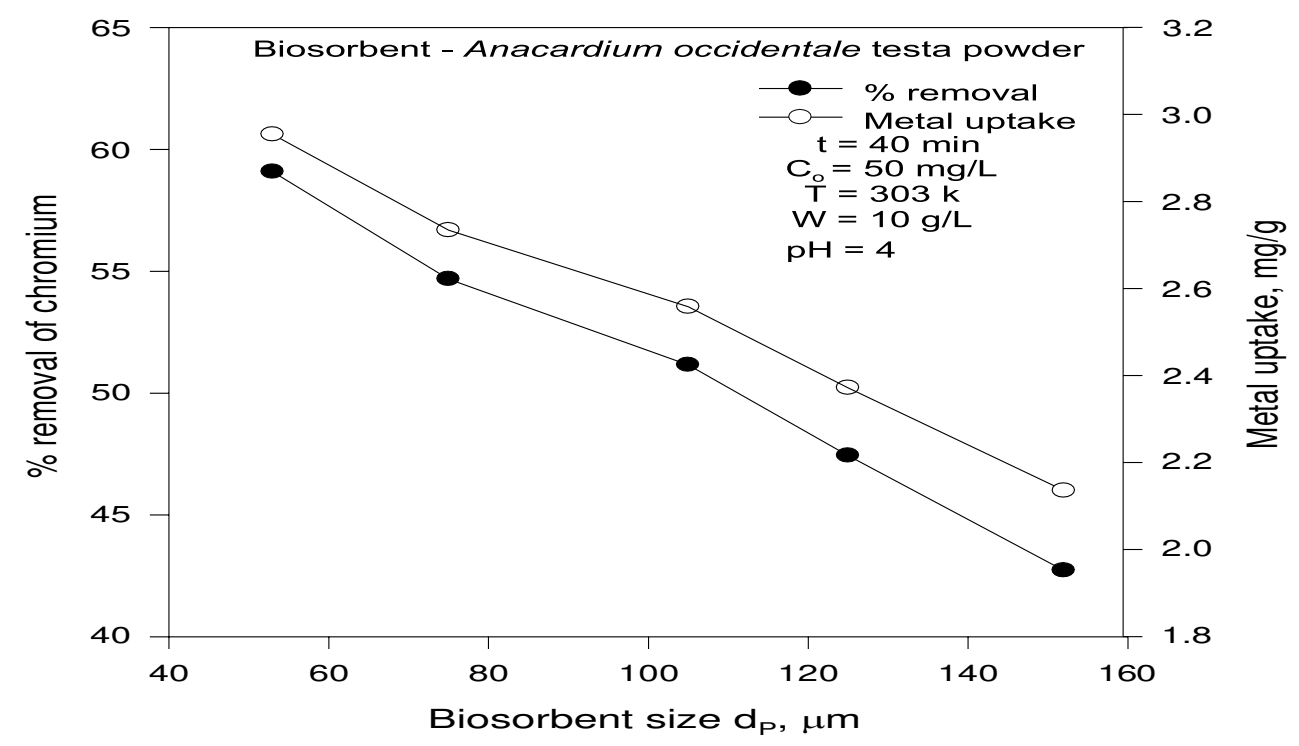

Fig.4 Effect of biosorbent size on \% biosorption of chromium

\section{Effect of pH}

$\mathrm{pH}$ controls biosorption by influencing the surface change of the biosorbent, the degree of ionization and the species of biosorbate. In the present investigation, chromium biosorption data are obtained in the $\mathrm{pH}$ range of 2 to 8 of the aqueous solution $\left(\mathrm{C}_{0}=50 \mathrm{mg} / \mathrm{L}\right)$ using $10 \mathrm{~g} / \mathrm{L}$ of $53 \mu \mathrm{m}$ size biosorbent and is shown in Figure 5. The \% biosorption of chromium is increased from $50.64 \%(2.532 \mathrm{mg} / \mathrm{g})$ to $65.36 \%(3.268 \mathrm{mg} / \mathrm{g})$ as $\mathrm{pH}$ is increased from 2 to 5 and decreased beyond the $\mathrm{pH}$ value of $5 \%$ biosorption is decreased from pH 6 to 8 reaching $63.52 \%(3.176 \mathrm{mg} / \mathrm{g})$ from $52.72 \%(2.636 \mathrm{mg} / \mathrm{g})$. Low $\mathrm{pH}$ decreases biosorption due to competition with $\mathrm{H}^{+}$ions for appropriate sites on the biosorbent surface. However, with increasing $\mathrm{pH}$, this competition weakens and Chromium ions replace $\mathrm{H}^{+}$ions bound to the biosorbent (Abdelwahab et al. 2007; Abbas et al. 2008)

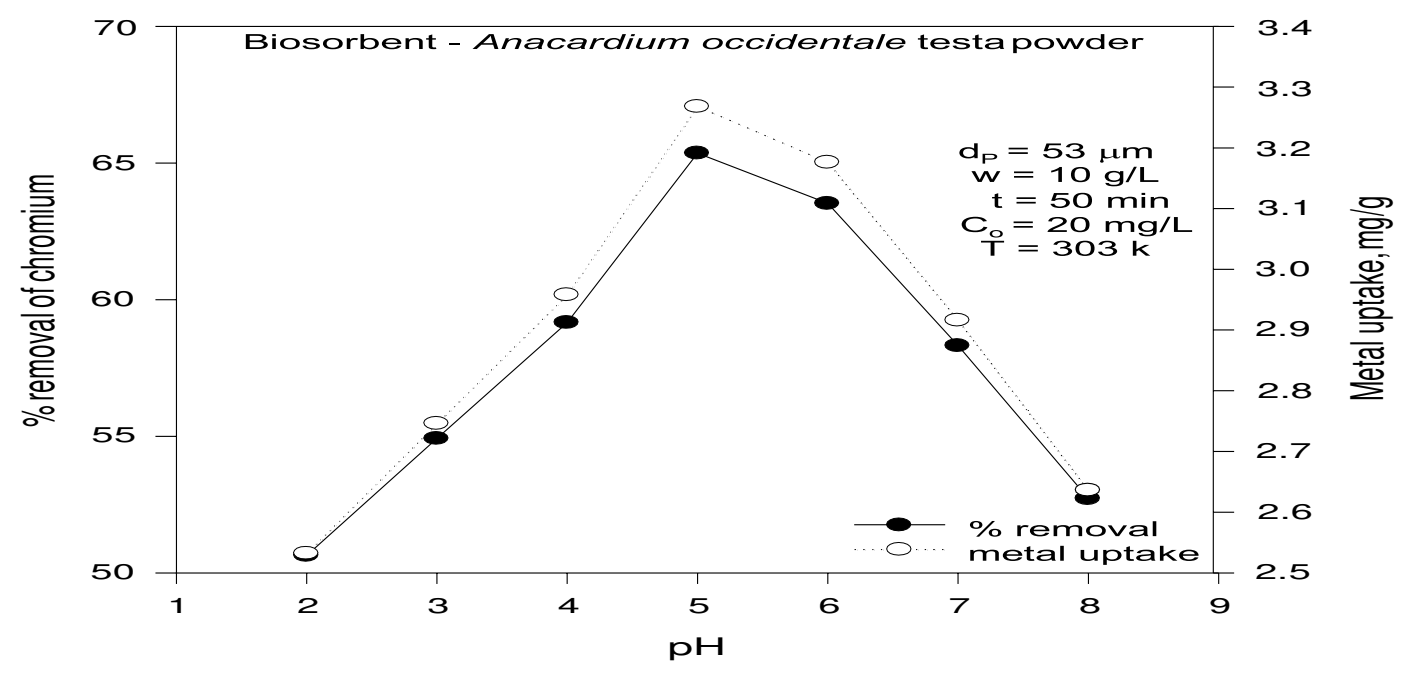




\section{Effect of initial concentration for the biosorption of chromium}

The effect of initial concentration of chromium in the aqueous solution on the percentage biosorption of chromium is shown in Figure 6. The percentage biosorption of chromium is decreased from 65.60 $\%(0.8375 \mathrm{mg} / \mathrm{g})$ to $43.99 \%\left(2.0492 \mathrm{mg} / \mathrm{g}\right.$ ) with an increase in $\mathrm{C}_{0}$ from $20 \mathrm{mg} / \mathrm{L}$ to $200 \mathrm{mg} / \mathrm{L}$ (Shen et al. 2007). Such behavior can be attributed to the increase in the amount of biosorbate to the unchanging number of available active sites on the biosorbent.

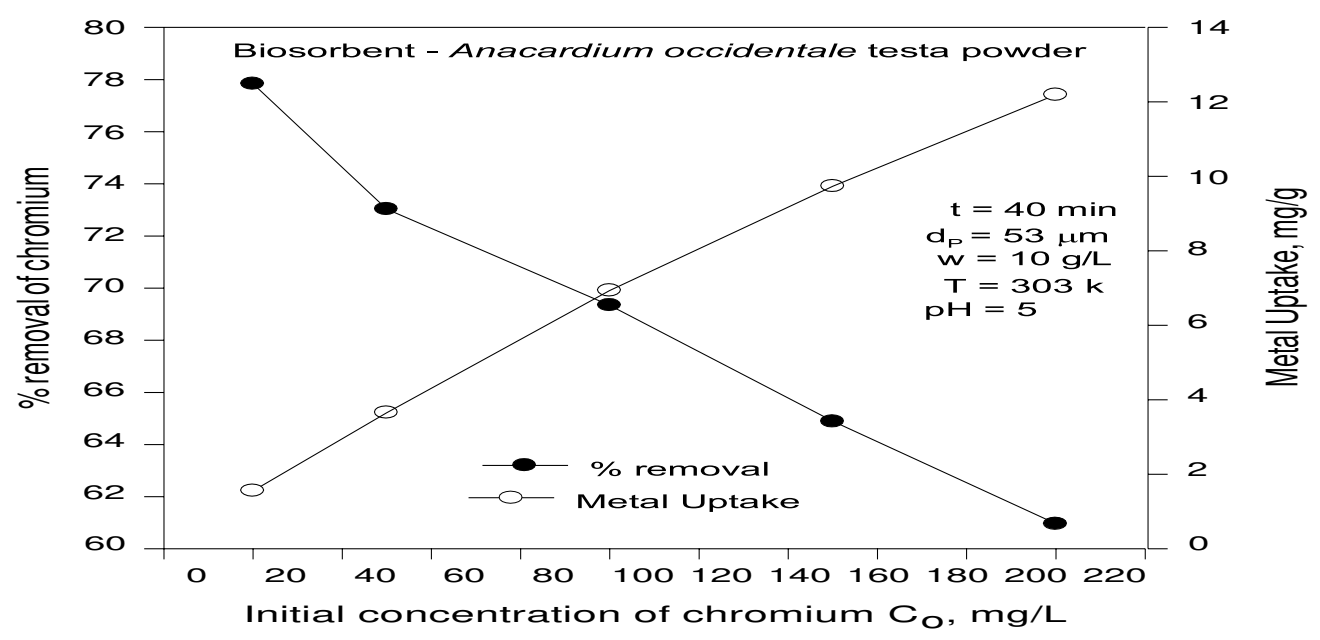

Fig.6 Effect of initial concentration for the biosorption of chromium

\section{Effect of biosorbent dosage}

The percentage biosorption of chromium is drawn against biosorbent dosage for $53 \mu \mathrm{m}$ size biosorbent in Figure7. The biosorption of chromium increased from $62.30 \%(2.4920 \mathrm{mg} / \mathrm{g})$ to 75.90

$\%(0.6072 \mathrm{mg} / \mathrm{g})$ with an increase in biosorbent dosage from 5 to $25 \mathrm{~g} / \mathrm{L}$. Such behavior is obvious because with an increase in biosorbent dosage, the number of active sites available for chromium biosorption would be more. The change in percentage biosorption of chromium is marginal from $75.90 \%(0.6072 \mathrm{mg} / \mathrm{g})$ to $78.40 \%(0.3136 \mathrm{mg} / \mathrm{g})$ when ' $\mathrm{w}$ ' is increased from 25 to $50 \mathrm{~g} / \mathrm{L}$. Hence all other experiments are conducted at $25 \mathrm{~g} / \mathrm{L}$ dosage (Gholamreza Moussavi and Behnam Barikbin 2010; Wang et al. 2009). 


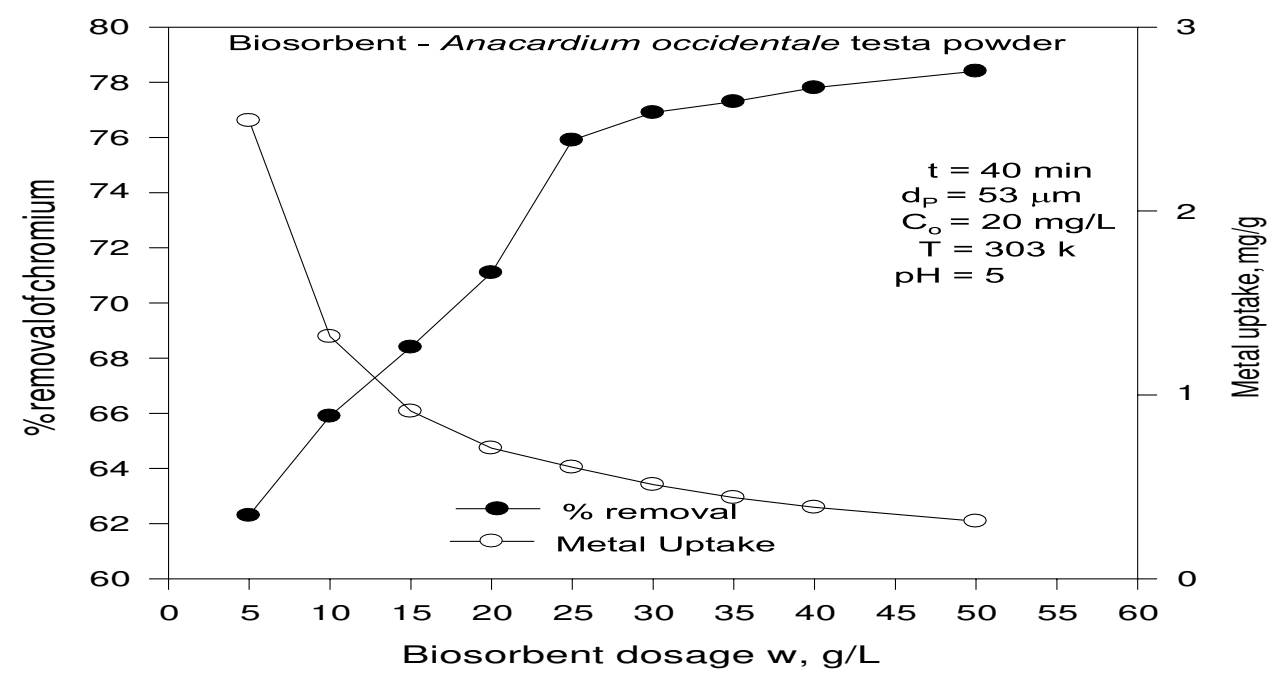

Fig.7 Effect of biosorbent dosage on \% biosorption of chromium

\section{Effect of Temperature}

The effect of temperature on the equilibrium metal uptake was significant. The effect of changes in the temperature on the chromium uptake is shown in Figure 8.

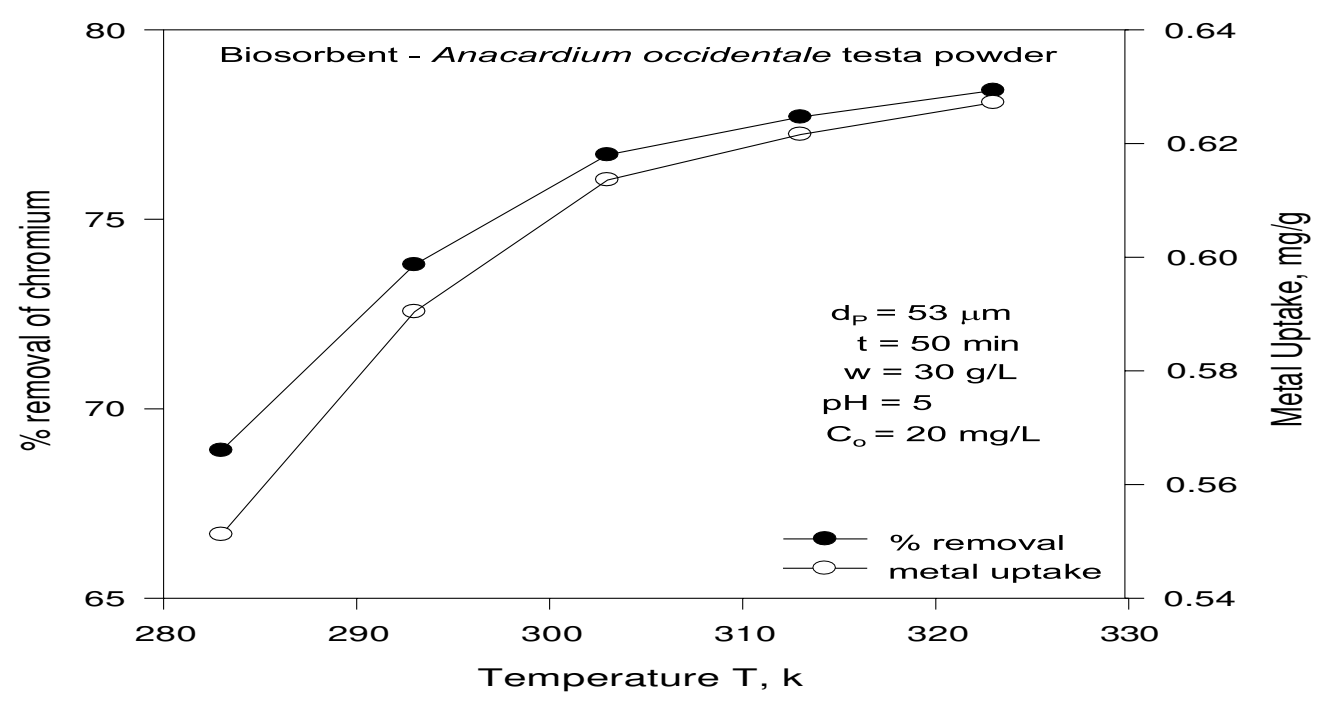

Fig.8 Effect of temperature for the biosorption of chromium

When temperature was lower than $303 \mathrm{~K}$, Chromium uptake increased with increasing temperature, but when temperature was over $303 \mathrm{~K}$, the results were on the contrary. This response suggested a different interaction between the ligands on the cell wall and the metal. Below $303 \mathrm{~K}$, chemical biosorption mechanisms played a dominant role in the whole biosorption process; biosorption was expected to increase by increase in the temperature (Gholamreza Moussavi and Behnam Barikbin 2010; Wang et al. 2009) while at higher temperature, the \% biosorption increased is very minute and 
marginal.

Isotherms for biosorption of chromium using Anacardium occidentale Testa Powder

\section{Langmuir isotherm}

Langmuir isotherm (Langmuir 1918) is drawn for the present data and shown in Figure 9. The equation obtained ' $\mathrm{n}$ ' $\mathrm{C}_{\mathrm{e}} / \mathrm{q}_{\mathrm{e}}=0.06843 \mathrm{C}_{\mathrm{e}}+5.05471$ with a good linearity (correlation coefficient, $\mathrm{R}^{2} \sim 0.9927$ ) indicating strong binding of chromium ions to the surface of Anacardium occidentale testa powder.

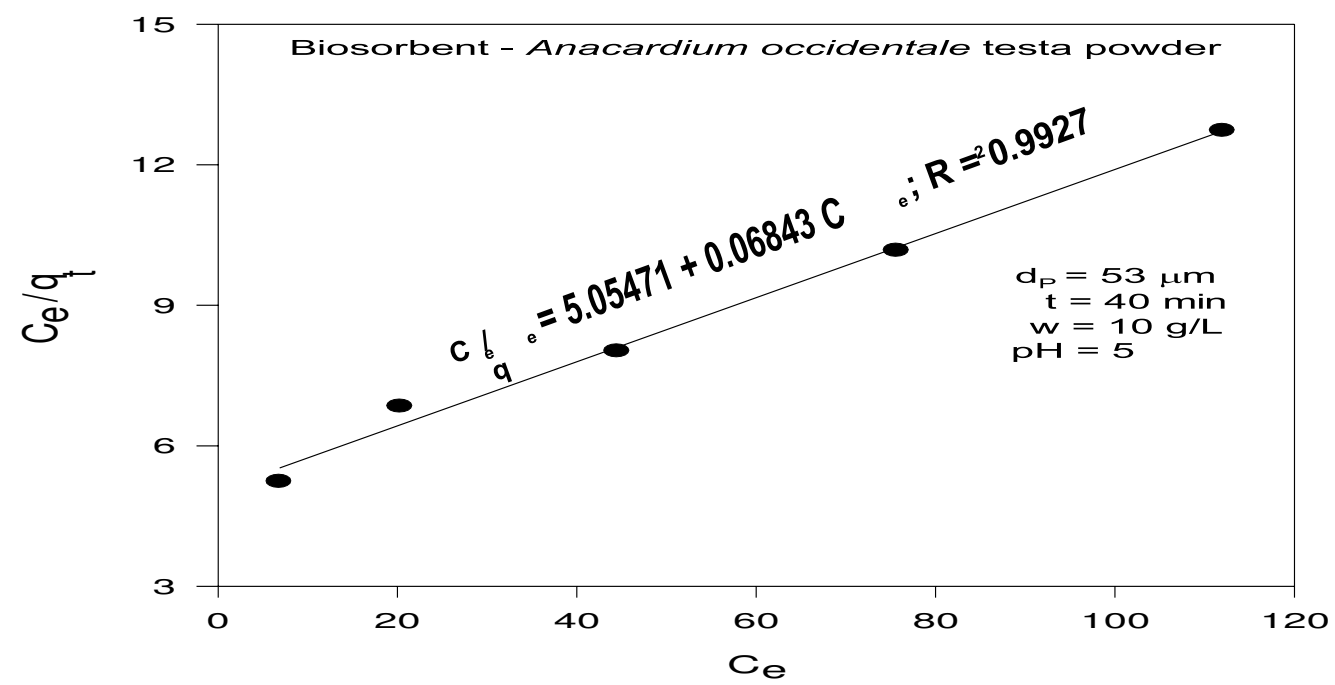

Fig.9 Langmuir isotherm for biosorption of chromium

\section{Freundlich isotherm}

Freundlich isotherm (Freundlich 1906) is drawn between $\ln \mathrm{q}_{\mathrm{e}}$ and $\ln \mathrm{C}_{\mathrm{e}}$ and is shown in Figure 10 and the resulted equation is $\ln \mathrm{q}_{\mathrm{e}}=0.69709 \ln \mathrm{C}_{\mathrm{e}}-1.02833$; the resulting equation has a correlation coefficient of 0.9920 . The ' $n$ ' value in the above equations satisfies the condition of $0<n<1$ indicating favorable biosorption. 


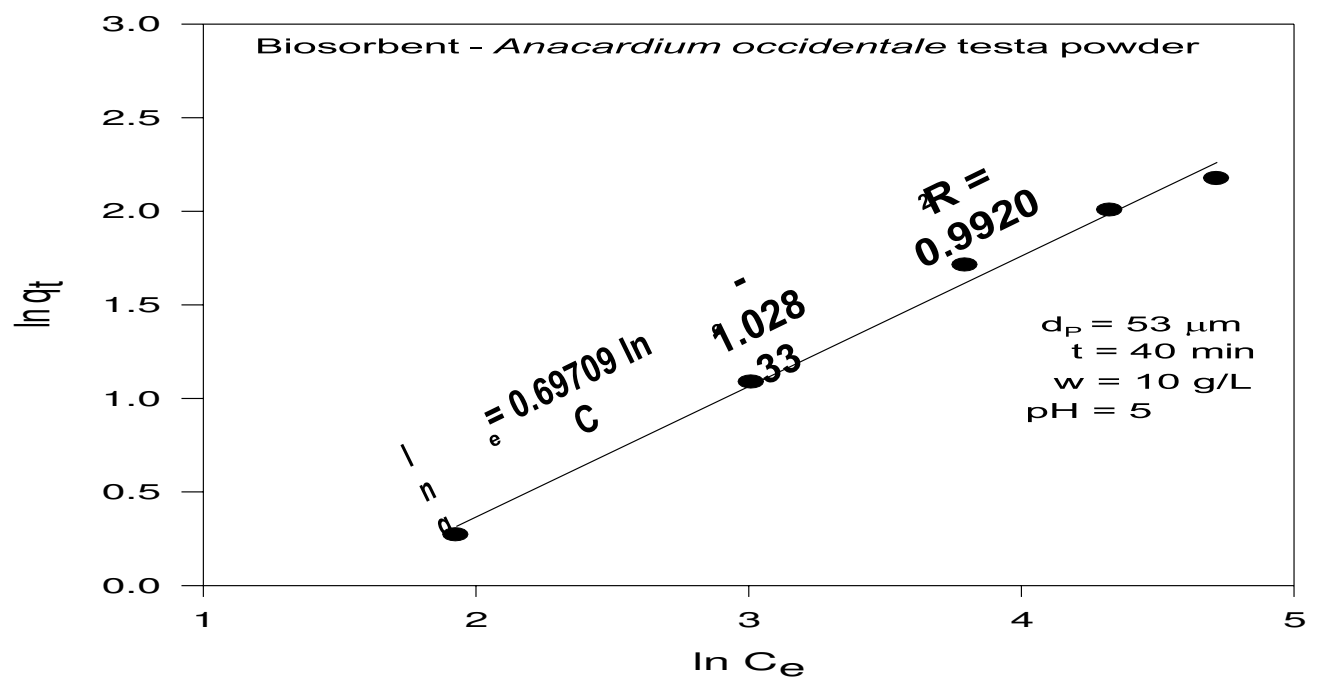

Fig.10 Freundlich isotherm for biosorption of chromium

\section{Temkin isotherm}

The present data are analyzed according to the linear form of Temkin isotherm (Temkin and Pyzhev 1940) and the linear plot is shown in Figure11.The equation obtained for chromium biosorption is $\mathrm{q}_{\mathrm{e}}$ $=2.73474 \ln \mathrm{C}_{\mathrm{e}}-4.5133$ with a correlation coefficient 0.9697 . The best fit model is determined based on the linear regression correlation coefficient (R). From the Figures 9, 10 and11 it is found that biosorption data are well represented by Langmuir isotherm with higher correlation coefficient of 0.9927, followed by Freundlich and Temkin isotherms with correlation coefficients of 0.9920 and 0.9697 respectively as shown in Table. 1 .

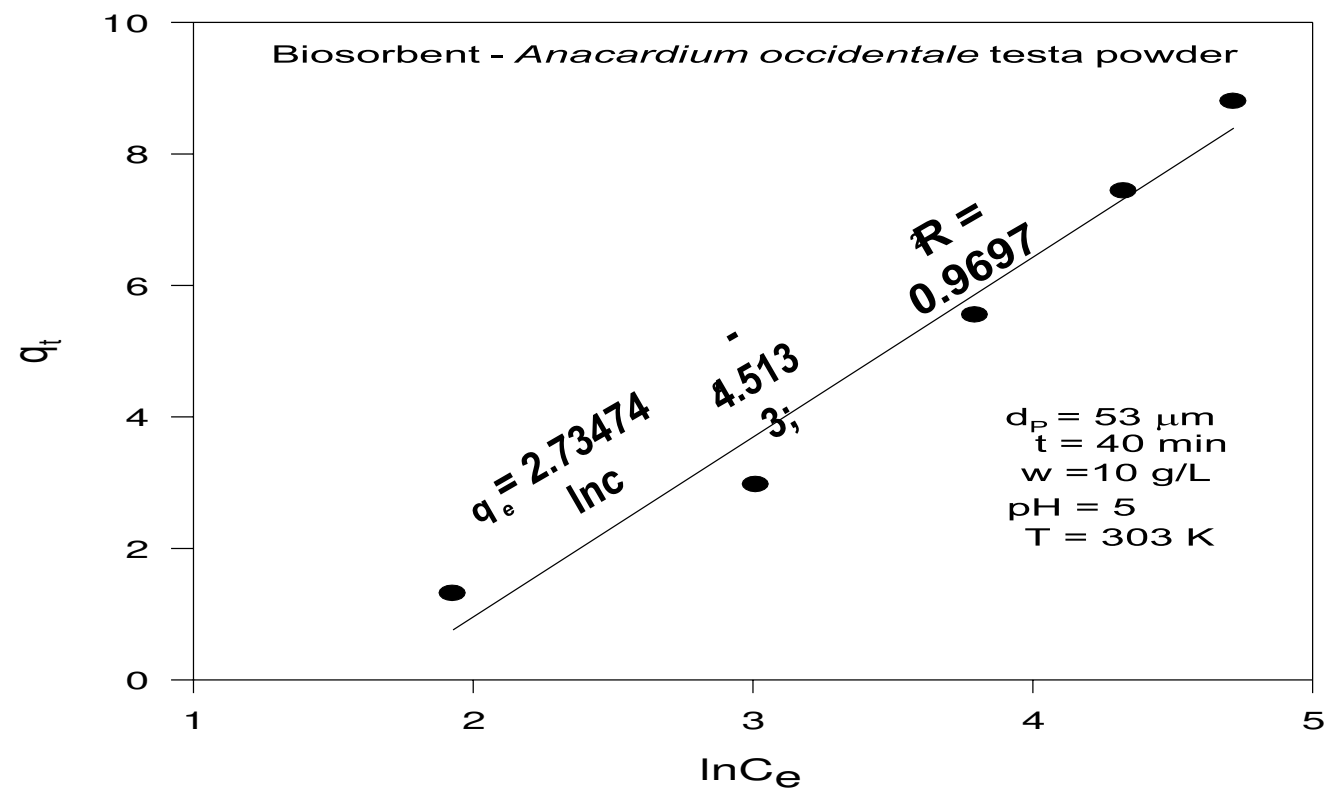

Fig.11Temkin isotherm for biosorption of chromium 


\section{Table1}

\section{Isotherms constants}

\begin{tabular}{l|l|l} 
Langmuir & Freundlich & Temkin \\
\hline $\mathrm{q}_{\mathrm{m}}=14.613$ & $\mathrm{k}_{\mathrm{f}}=0.3576$ & $\mathrm{~A}_{\mathrm{T}}=0.2287$ \\
\hline $\mathrm{b}=0.0135$ & $\mathrm{n}=0.69709$ & $\mathrm{~b}_{\mathrm{T}}=3613.79$ \\
\hline $\mathrm{R}^{2}=0.9927$ & $\mathrm{R}^{2}=0.9920$ & $\mathrm{R}^{2}=0.9697$
\end{tabular}

\section{Kinetics of biosorption}

In the present study, the kinetics are investigated with $50 \mathrm{~mL}$ of aqueous solution $\left(\mathrm{C}_{0}=20 \mathrm{mg} / \mathrm{L}\right)$ at $303 \mathrm{~K}$ with the interaction time intervals of $1 \mathrm{~min}$ to $180 \mathrm{~min}$. Lagergren (Lagergren 1898) plots of $\log \left(\mathrm{q}_{\mathrm{e}}-\mathrm{q}_{\mathrm{t}}\right)$ versus agitation time $(\mathrm{t})$ for biosorption of chromium the biosorbent size $(53 \mu \mathrm{m})$ of Anacardium occidentale testa powder in the interaction time intervals of 1 to $180 \mathrm{~min}$, first order kinetics and second order kinetics are drawn in Figures12, 13

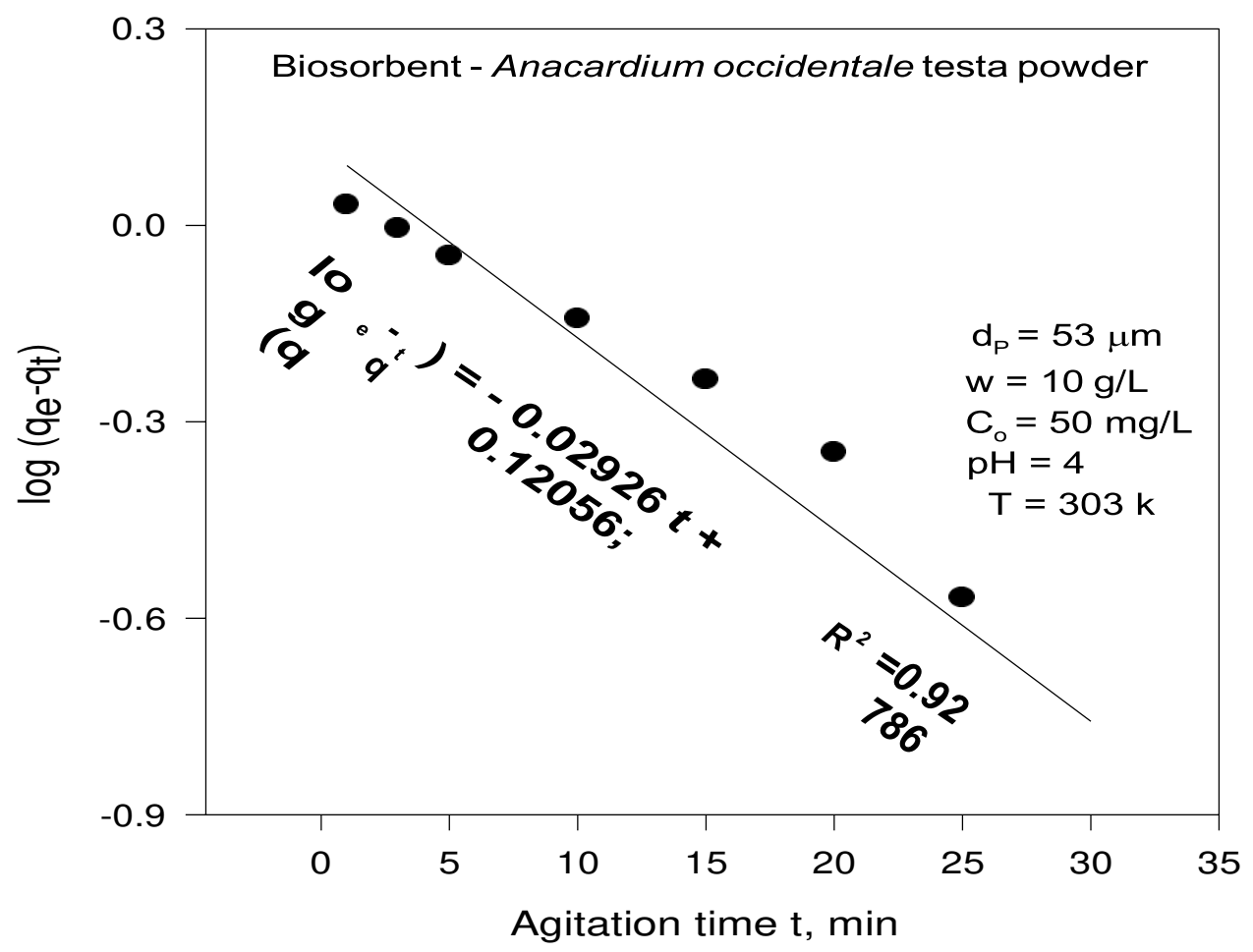

Fig.12 First order kinetics for biosorption of chromium 


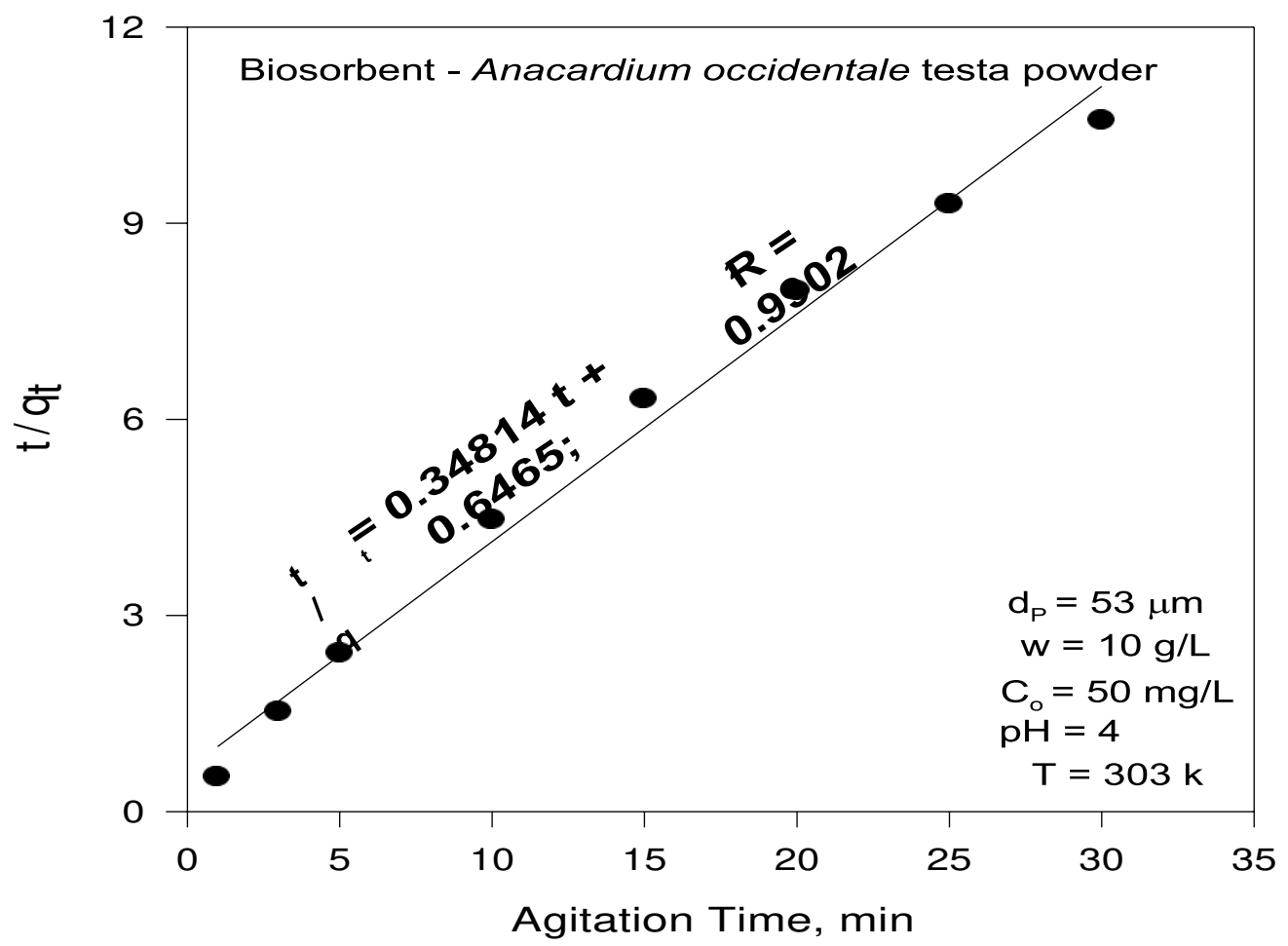

Fig.13 Second order Kinetics for biosorption of chromium

Table 2

Equations and rate constants

\begin{tabular}{l|l|l|l} 
Order & Equation & Rate constants & \multicolumn{2}{l}{$\boldsymbol{R}^{\mathbf{2}}$} \\
\hline $\begin{array}{l}\text { Lagergren } \\
\text { first order }\end{array}$ & $\log \left(\mathrm{q}_{\mathrm{e}}-\mathrm{q}_{\mathrm{t}}\right)=-0.02926 \mathrm{t}-0.12056$ & $0.06738 \mathrm{~min}^{-1}$ & 0.9278 \\
& & & \\
$\begin{array}{l}\text { Pseudo } \\
\text { second } \text { order } / \mathrm{q}_{\mathrm{t}}=0.3481 \mathrm{t}+0.6465\end{array}$ & $0.1874 \mathrm{~g} /(\mathrm{mg}-\mathrm{min})$ & 0.9902 \\
& &
\end{tabular}

As the correlation coefficient value for the pseudo second order kinetics (Ho and McKay 1999) is 0.9902, we can say that the pseudo second order kinetics describes the mechanism of chromium using Anacardium occidentale testa powder interactions are better. 


\section{Thermodynamics of biosorption}

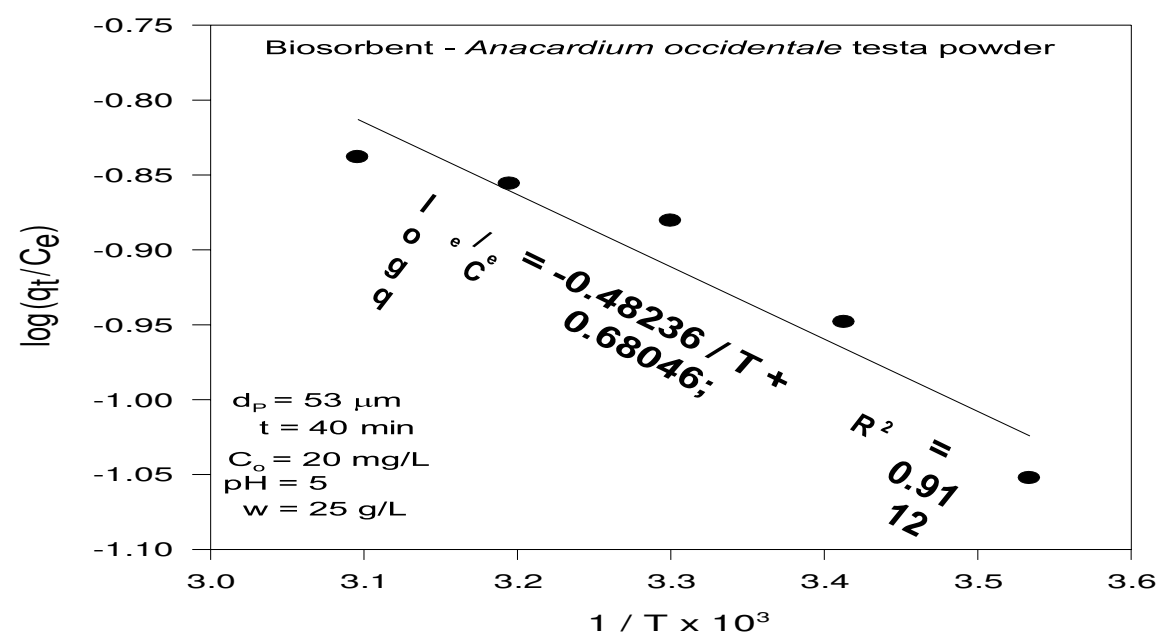

Fig.14 Van'thoff plot for biosorption

Experiments are conducted to understand the biosorption behavior varying the temperature from 283 to $323 \mathrm{~K}$. The Van'thoff plot indicating the effect of temperature on biosorption of chromium is shown in Fig.14. In the present investigation, $\Delta \mathrm{H}=9.2358 \mathrm{~J} / \mathrm{mole}, \Delta \mathrm{S}=13.0288 \mathrm{~J} / \mathrm{mole}-\mathrm{K}$ and $\Delta \mathrm{G}=$ $-3938.50876 \mathrm{~J} / \mathrm{mole} . \Delta \mathrm{H}$ is positive indicating that the biosorption is endothermic. The negative value of $\Delta \mathrm{G}$ indicates the spontaneity of biosorption. As $\Delta \mathrm{S}$ is more than zero, it indicates the irreversibility of biosorption.

\section{Conclusion}

The Anacardium occidentale testa powder was used as an effective low cost biosorbent for the removal of chromium in aqueous solution. The equilibrium agitation time for chromium biosorption was 40 minutes. The percentage removal of chromium increased significantly with an increase in biosorbent dosage from 5 to $25 \mathrm{~g} / \mathrm{L}$ at $\mathrm{pH} 5$ and with an increase in the initial concentration of chromium in the aqueous solution, the percentage removal of chromium from the aqueous solution is decreased. In the range of variables optimized, percentage removal of chromium increased from $37.64 \%(1.882 \mathrm{mg} / \mathrm{g})$ to $78.4 \%(0.6272 \mathrm{mg} / \mathrm{g})$. The maximum uptake capacity of $14.613 \mathrm{mg} / \mathrm{g}$ is obtained at $303 \mathrm{~K}$. Langmuir equilibrium isotherm model proved to be good fit for the experimental data of chromium biosorption on Anacardium occidentale testa powder. The kinetics of the biosorption of chromium described by a pseudo-second-order kinetic model with $R^{2} 0.9927$. Free energy change $\left(\mathrm{D} G^{\circ}\right)$ with negative sign reflects the feasibility and spontaneous nature of the process. The positive enthalpy values indicate endothermic in nature. Anacardium occidentale testa powder can be used in cleaning chromium polluted water and it is eco-friendly, effective, affordable. 


\section{Acknowledgments}

The authors are grateful to Department of Chemical engineering, Andhra University, Vishakhapatnam, for providing the necessary laboratory facilities during the course of this study.

\section{Author's contributions}

CG \& SG designed and conducted experiments, collected data and prepared the manuscript. SVN reviewed and provided comments and finalized the manuscript. All authors read and approved the final manuscript

\section{Funding}

Not applicable

\section{Availability of data and materials}

All data generated or analyzed during this study are included in this article.

\section{Declarations}

\section{Ethics approval and consent to participate}

Not applicable.

\section{Consent for publication}

All authors consent to publishing the manuscript in Bioresources and Bioprocessing. There is no conflict of interest for any of the authors regarding the submission of this manuscript.

\section{Competing interests}

The authors declare no competing interests.

\section{Author details}

${ }^{1 *}$ Department of Chemistry, Mahathi College of Pharmacy, Madanapalli, Andhra Pradesh, 517319,India. ${ }^{1,2}$ Center for Biotechnology, Department of Chemical Engineering, Andhra University,Visakhapatnam,530003, India.

\section{References}

1. Abbas M, Nadeem R, Zafar MN, Arshad M (2008) Biosorption of chromium (III) and chromium (VI) by untreated and pretreated Cassia fistula biomass from aqueous solutions. Water Air and Soil Pollution 191(1):139-148. https://doi.org/10.1007/s11270- 007-9613-8

2. Abdelwahab O, El Sikaily A, Khaled A, El Nemr A (2007) Mass-transfer processes of chromium (VI) adsorption onto guava seeds. Chemistry and ecology 23(1):73-85. https://doi.org/10.1080/02757540601083922

3. Yun Wang, Yingxia Li, Feng Juan Zhao (2014) Bisorption of chromium (VI) from aqueous solutions by Sargassum thunbergii Kuntze. Biotechnology and Biotechnological 
Equipment 28(2):259-265. https://doi.org/10.1080/13102818.2014.907028

4. Avudainayagam S, Megharaj M, Owens G, RaiKookana S, Chittle borough D, Naidu R (2003) Chemistry of chromium in soils with emphasis on tannery waste sites. Reviews of environmental contamination and toxicology 178:53-91. https://doi.org/10.1007/0-38721728-2_3

5. Basu M, Guha AK, Ray L (2017) Adsorption of lead on cucumber peel. Journal of cleaner production 151: 603-615. https://doi.org/10.1016/j.jclepro.2017.03.028

6. Calero MPA, Blázquez G, Ronda A, Martín-Lara MA (2013), Characterization of chemically modified biosorbents from olive tree pruning for the biosorption of lead. Ecological engineering 58: 344-354. https://doi.org/10.1016/j.ecoleng.2013.07.012

7. Cutillas Barreiro L, Paradelo R, Igrexas Soto A, Núñez Delgado A, Fernández Sanjurjo MJ, Álvarez-Rodriguez E, Garrote G, Nóvoa Muñoz JC, Arias Estévez M (2016) Valorization of biosorbent obtained from a forestry waste: Competitive adsorption, desorption and transport of $\mathrm{Cd}, \mathrm{Cu}, \mathrm{Ni}, \mathrm{Pb}$ and $\mathrm{Zn}$, Ecotoxicology and environmental safety 131 :118126.https://doi.org/10.1016/j.jenvman.2014.06.008.

8. Dhankhar R, Hooda A (2011) Fungal biosorption-an alternative to meet the challenges of heavy metal pollution in aqueous solutions. Environmental technology 32 (5):467-491. https://doi.org/10.1080/09593330.2011.572922

9. Ding Z, Hu X, Zimmerman AR, Gao B (2014) Sorption and cosorption of lead (II) and methylene blue on chemically modified biomass. Bioresource technology 167: 569-573. https://scite.ai/reports/10.1016/j.biortech.2014.06.043

10. Donkoh A, Attoh Kotoku V, Osei Kwame R, Gascar R (2012) Evaluation of nutritional quality of dried cashew nut testa using laboratory rat as a model for pigs. The Scientific World Journal1-5. https://doi.org/10.1100/2012/984249

11. Dube BK, Tewari K, Chatterjee J, Chatterjee C (2003) Excess chromium alters uptake and translocation of certain nutrients in citrullus Chemosphere 53 (9): 1147-1153. https://doi: 10.1016/S0045-6535(03)00570-8

12. Dwivedi S, Srivastava S, Mishra S, Kumar A, Tripathi RD, Rai UN, Dave R, Tripathi P, Charkrabarty D, Trivedi PK (2010) Characterization of native micro algal strains for their chromium bioaccumulation potential: Phytoplankton response in polluted habitats. Journal of hazardous materials 173 (1-3): 95-101. https://doi: 10.1016/j.jhazmat.2009.08.053.

13. Fu F, Wang Q (2011) Removal of heavy metal ions from wastewaters: a review. Journal of environmental management 92 (3) : 407-418.https://doi: 10.106/j.jenvman.2010.11.011

14. Gale TF (1978) Embryotoxic effects of chromium trioxide in hamsters. Environmental Research 16 (1-3): 01-109. doi: 10.1016/0013-9351(78)90147-0.

15. Gholamreza Moussavi, Behnam Barikbin (2010) Biosorption of chromium (VI) from industrial wastewater onto pistachio hull waste biomass. Chemical Engineering 
Journal162: 893-900. https://doi:10.1016/j.cej.2010.06.032

16. Ho YS, McKay G (1999) Pseudo-second order model for sorption processes. Process Biochemistry 34: 451-465. https://doi.org/10.1016/S0032-9592(98)00112-5

17. Wael MI, Asad FH, Yahia AA (2016) Biosorption of toxic heavy metals from aqueous solution by Ulva lactuca activated carbon. Egyptian Journal of Basic and Applied Sciences 3:3, 241-249. https://doi:10.1016/j.ejbas.2016.07.005

18. Karthikeyan T, Rajgopal S, Miranda LR (2005) Chromium (VI) adsorption from aqueous solution by Hevea brasilinesis sawdust activated carbon. Journal of hazardous materials 124 (1-3):192-199. https://doi:10.1016/j.jhazmat.2005.05.003.

19. Kümmerer K (2009) The presence of pharmaceuticals in the environment due to human use-present knowledge and future challenges, Journal of environmental management 90 (8): 2354-2366. https://doi: 10.1016/j.jenvman.2009.01.023.

20. Lagergren S (1898) On the theory of so called adsorption of dissolved substances, Handlingar24: 1-39.

21. Langmuir I (1918) The Adsorption of Gases on Plane Surface of Glass, Mica and Olatinum. Journal of the American Chemical Society 40:1361-1403. http://dx.doi.org/10.1021/ja02242a004.

22. Liu T, Li H, Li Z, Xiao X, Chen L, Deng L (2007) Removal of hexavalent chromium by fungal biomass of Mucor racemosus: influencing factors and removal mechanism, World Journal of Microbiology and Biotechnology 23(12):1685-1693. https://doi: 10.1007/s11274-007-9416-5.

23. Mahmood-ul-Hassan M, Suthor V, Rafique E, Yasin M(2015) Removal of Cd, Cr, and Pb from aqueous solution by unmodified and modified agricultural wastes. Environmental monitoring and assessment 187 (2) : 42-58.https://doi:10.1007/s10661-014-4258-8

24. Marchese M, Gagneten AM, Parma MJ, Pavé PJ (2008) Accumulation and elimination of chromium by freshwater species exposed to spiked sediments. Archives of environmental contamination and toxicology 55 (4): 603-609. https://doi: 10.1007/s00244-008-9139-0.

25. Masukume M, Onyango MS, Maree JP (2014) Sea shell derived adsorbent and its potential for treating acid mine drainage. International Journal of Mineral Processing 133: 52-59. https:// 10.1016/j.minpro.2014.09.005

26. Mohan D, Singh KP (2002) Single and multi-component biosorption of cadmium and zinc using activated carbon derived from bagasse an agricultural waste. Water Res. 36: 23042318. https:// doi: 10.1016/s0043-1354(01)00447-x

27. Morosanu I, Teodosiu C, Paduraru C, Ibanescu D, Tofan L (2017) Biosorption of lead ions from aqueous effluents by rapeseed biomass. New biotechnology 39:110- 124 . https:// doi:10.1016/j.nbt.2016.08.002 
28. Mungasavalli DP, Viraraghavan T, Jin YC (2007) Biosorption of chromium from aqueous solutions by pretreated Aspergillus niger: batch and column studies. Colloids and Surfaces A: Physicochemical and Engineering Aspects 301 (1-3): 214-223. https://doi:10.1016/j.colsurfa.2006.12.060

29. Nguyen TAH, Ngo HH, Guo WS, Zhang J, Liang S, Yue QY, Li Q, Nguyen TV(2013) Applicability of agricultural waste and by-products for adsorptive removal of heavy metals from wastewater. Bioresource technology 148:574-585.https://doi: 10.1016/j.biortech.2013.08.124.

30. Ofomaja AE, Naidoo EB (2010) Biosorption of lead (II) onto pine cone powder: studies on biosorption performance and process design to minimize biosorbent mass, Carbohydrate Polymers 82 (4): 1031-1042. https://doi:10.1016/j.carbpol.2010.05.024

31. Petrilli FL, Flora De S (1977) Toxicity and mutagenicity of hexavalent chromium on Salmonella typhimurium. Applied and Environmental Microbiology 33 (4): 805-809. https://doi: 0.1128/aem.33.4.805-809.1977.

32. Rao Popuri S, Jammala A, Naga Suresh Reddy KV, Abburi K (2007) Biosorption of hexavalent chromium using tamarind (Tamarindus indica) fruit shell-a comparative study. Electronic Journal of Biotechnology 10 (3): 358-367. https://doi:10.2225/vol10-issue3fulltext-11

33. Shanker AK, Cervantes C, Loza-Tavera H, Avudainayagam S (2005) Chromium toxicity $\begin{array}{lllll}\text { in } & \text { plants. } & \text { Environment } & \text { international } & \end{array}$ https://doi:10.1016/j.envint.2005.02.003

34. Shen L, Xia JL, He H, Nie ZY, Qiu GZ (2007) Biosorption mechanism of Cr (VI) onto cells of Synechococcus sp. Journal of Central South University of Technology 14(2) : 157- 162. https://doi:10.1007/s11771-007-0032-1

35. Temkin MJ, Pyzhev V (1940) Recent Modifications to Langmuir Isotherms. Acta Physiochim URSS12, 217- 225.

36. Velma V, Vutukuru SS, Tchounwou PB (2009) Ecotoxicology of hexavalent chromium in freshwater fish: a critical review. Reviews on environmental health 24 (2): 129-145. https://doi:10.1515/reveh.2009.24.2.129.

37. Wang XS, Li ZZ, Tao SR (2009) Removal of chromium (VI) from aqueous solution using walnut hul. Journal of Environmental Management 90 (2): 721-729. https://doi:10.1016/j.jenvman.2008.01.011.

38. Waseem S, Din MI, Nasir S, Rasool A (2014).Evaluation of Acacia nilotica as a nonconventional low cost biosorbent for the elimination of $\mathrm{Pb}$ (II) and $\mathrm{Cd}$ (II) ions from aqueous solutions. Arabian Journal of Chemistry 7 (6): 1091-1098. https://doi.org/10.1016/j.arabjc.2012.03.020 
39. Zayed AM, Terry N (2003). Chromium in the environment: factors affecting biological remediation. Plant and soil 249 (1): 139-156.https://doi.org/10.1023/A:1022504826342

40. Zhang D, Wang C, Bao Q, Zheng J, Deng D, Duan Y, Shen L (2018). The physicochemical characterization, equilibrium, and kinetics of heavy metal ions adsorption from aqueous solution by arrowhead plant (Sagittariatrifolia L.) stalk. Journal of Food Biochemistry 42 (1): 12448. https://doi.org/10.1111/jfbc.12448

41. Zhang T, Wang Y, Kuang Y, Yang R, Ma J, Zhao S, Liao Y, Mao H (2017) Adsorptive removal of $\mathrm{Cr}^{3+}$ from aqueous solutions using chitosan microfibers immobilized with plant polyphenols as biosorbents with high capacity and selectivity. Applied Surface Science 404: 418-425. https://doi.org/10.1016/j.apsusc.2017.02.018 